\title{
Managing enthusiasm: between 'extremist' volunteers and 'rational' professional practices in architectural conservation
}

Article

Accepted Version

Creative Commons: Attribution-Noncommercial-No Derivative Works 4.0

Craggs, R., Geoghegan, H. and Neate, H. (2016) Managing enthusiasm: between 'extremist' volunteers and 'rational' professional practices in architectural conservation. Geoforum, 74. pp. 1-8. ISSN 0016-7185 doi:

https://doi.org/10.1016/j.geoforum.2016.05.004 Available at https://centaur.reading.ac.uk/65765/

It is advisable to refer to the publisher's version if you intend to cite from the work. See Guidance on citing.

To link to this article DOI: http://dx.doi.org/10.1016/j.geoforum.2016.05.004

Publisher: Elsevier

All outputs in CentAUR are protected by Intellectual Property Rights law, including copyright law. Copyright and IPR is retained by the creators or other copyright holders. Terms and conditions for use of this material are defined in the End User Agreement.

www.reading.ac.uk/centaur 
Central Archive at the University of Reading

Reading's research outputs online 
**Manuscript accepted for publication in Geoforum $18^{\text {th }}$ May 2016**

Managing Enthusiasm: Between 'Extremist' Volunteers and 'Rational'

Professional Practices in Architectural Conservation

Author names and affiliations (*corresponding author)

Ruth Craggs

King's College London

Address: $\quad$ Department of Geography

King's College London

King's Building

Strand Campus

London

WC2R 2LS

Email: ruth.craggs@kcl.ac.uk

Hilary Geoghegan

University of Reading

Address: Department of Geography \& Environmental Science

University of Reading

Whiteknights Campus

Reading

Berkshire

RG6 6AB

Email: $\quad$ h.geoghegan@reading.ac.uk

Hannah Neate*

Manchester Metropolitan University

Address: Division of Geography \& Environmental Management

Manchester Metropolitan University

Manchester

Chester Street

M15 6BH

Email: h.neate@mmu.ac.uk 


\begin{abstract}
Recent geographical research has considered enthusiasm to be a shared passion and a motivator to action. Through the example of architectural conservation in Britain, and the activities of the Twentieth Century Society in particular, this paper examines the tensions between enthusiasm as a productive and positive affiliation, and enthusiasm as a negative, prohibitive, and at times extremist position. The paper makes three key contributions: firstly, it demonstrates how methodologically it is possible to trace enthusiasm, using ethnographic method to reveal not only what groups say they do, but also what they actually do. Secondly, it argues that enthusiasm is a productive but ambivalent term that creates tensions within organisations and societies where professional and volunteer roles are present. Thirdly, we show that even though enthusiasm has productive capacities, it also requires careful management, and on occasion denial. The tensions between enthusiasm and professionalism that we trace are relevant beyond the realm of architectural conservation and resonate with other groups comprised of volunteers and professionals.
\end{abstract}

\title{
Keywords
}

\section{Enthusiasm, Architecture, Conservation, Amateur, Professional, Volunteering}

\section{Introduction}

In popular understandings, enthusiasm is often seen as a positive emotion capable of inspiring study, dedication and/or voluntary work. Recent work in geography has focused on enthusiasm as a shared passion and a motivator to action (DeLyser and Greenstein, 2015; Everett and Geoghegan, 2015; Geoghegan, 2009; The Authors, 2013). Historically however, enthusiasm was associated with frenzy and religious fanaticism, and these negative connotations have never entirely been left behind (Geoghegan, 2009). In this paper we explore how the tensions between enthusiasm as a positive and productive affiliation, and enthusiasm as negative and prohibitive, influence the practices of architectural conservation. Focusing on the work of the Twentieth Century Society, a British-based amenity society which campaigns for the protection of modern architecture (buildings dating from 1918 onwards), we examine the role of enthusiasm in 
motivating volunteers and staff, and in supporting conservation work. In doing so we also demonstrate the ways in which enthusiasm at times challenges or constrains the Society's ability to contribute to conservation practice.

In this paper, enthusiasm is explored across a range of activities in which the Society is engaged. These fall into two broad categories: first, the social and educational functions, which are part of the Twentieth Century Society's enthusiast 'club' role and organised in large part by volunteers; and second, the labour of campaigning for buildings at risk, commenting on planning applications, and decisions over whether buildings should be afforded protection in law through what is known as 'listing'. The latter role is part of a statutory function that the Society performs, as part of formal planning procedures, and is led by paid Society staff, supported, again, by volunteers. Although enthusiasm for architecture is often located in the social, club side of the Society by those involved, this paper shows that enthusiasm plays a crucial role across the Society's activities.

Understanding the role of enthusiasm in the Twentieth Century Society makes important contributions to a range of debates. First, the Society is just one of a whole range of architectural amenity societies that play an important, though often unacknowledged, role in planning decisions and the valuation of built heritage. Enthusiasm, we argue, has an important and overlooked role in architectural conservation that we begin to elucidate here. Existing research has explored architectural conservation from the angles of planning policy and the technicalities of conservation (e.g. While 2007). Here we explore enthusiasm as motivator for care and action, as well as destabiliser of 'expert' status, thereby contributing to a fuller understanding of how architectural value is arrived at and what elements of the built landscape are conserved (or not).

Second, emotion is a crucial element of volunteering and activism. Voluntary work is both valuable and on the rise. Volunteering is "becoming increasingly politicised" in the context of cuts to public services and increasing partnerships between the state and voluntary sector (Mills, 2015, p.523). English Heritage argued in their 2011 report entitled Heritage Counts that heritage organisations have a long-standing record of providing invaluable support to local communities, and that civic societies are well placed to represent community views to local 
authorities and others. Some $85 \%$ of civic societies currently respond to planning applications and $46 \%$ provide advice on planning issues. Yet knowledge about groups such as the Twentieth Century Society is sketchy at best (Hemming, 2011). Exploring the role of enthusiasm as a motivator for volunteer work in architectural conservation contributes to a broader debate around the role of, and experience of, volunteers in society (Jupp, 2012; Roberts and Devine, 2004). It builds on recent research that has called for 'enlivened' accounts of volunteer practices that are attentive to the role of emotion in motivating people to commit to campaigns that may be time-consuming, relentless, are often likely to be unsuccessful, and which understand voluntary action as "situated, emotional and embodied" (Smith et al., 2010, p. 258; Chatterton and Pickerill, 2010; Brown and Pickerill, 2009a; 2009b).

Finally, while enthusiasm can be seen as a positive, empowering emotion, we demonstrate that its role as both motivator and destabiliser of conservation work highlights the ambiguity surrounding enthusiasm. Understood as a threat to rationality and professional practice, enthusiasm can be suppressed, side-lined, or denied in conservation practice, with consequences for the range of strategies available in architectural campaigning. By unpicking these tensions, we are able to highlight how enthusiasm is present across a range of practices even when actively denied. This serves to provide a fuller understanding of conservation work, and to suggest alternative ways in which enthusiasm might be utilised in the practice of architectural conservation.

\section{The Geographies of Enthusiasm}

Enthusiasm has been defined as "an emotional affiliation that influences our passions, performances and actions in space" (Geoghegan, 2013, p. 45). Often a shared affiliation, geographers have shown how enthusiasm is central to practices such as the restoration of vintage cars (DeLyser and Greenstein, 2015), the recording of industrial archeology (Geoghegan, 2009), the dissemination of architectural knowledge (The Authors, 2013), or the participation of volunteers in nature surveys (Everett and Geoghegan, 2015). Enthusiasm matters because it has the capacity to move people and to result in change (Geoghegan, 2013). Decisions to study, 
collect, record, care, share, campaign, spend and exchange, and the emotions and knowledges such practices afford, in turn add to and influence wider spheres beyond the 'hobby' in question. In the case of architectural conservation, enthusiasm-knowledge contributes to planning processes, and the protection and conservation of buildings and artefacts. Enthusiasm for architectural conservation is not always about avoiding change, standing still or going backwards, rather architectural enthusiasm mobilises people, emotions and knowledges that can drive the safeguarding and protection of architecture and design. Architectural enthusiasts draw attention to architectural features, processes, materials and ideas often ignored or overlooked by public and professional audiences.

Enthusiasm for architecture makes buildings 'matter' as individuals and groups engage with them in various ways, including visiting buildings, photographing them, recording visits online, and campaigning to save them (The Authors, 2013, p. 881; Bennett, 2011; Kitson, 2015). Understanding enthusiasm as productive in this way means adding enthusiasts, and enthusiast groups, to the growing list of agents - alongside architects, planners, construction and maintenance workers, and residents - that scholars must account for in understanding how architecture is 'practised' Jacobs and Merriman, 2011; Lees and Baxter, 2011; The Authors, 2013). Through an examination of the work of an architectural amenity society we show how architectural enthusiasm, while often associated with leisure time and amateur pursuits, is nonetheless "strongly embedded within a politics of conservation" (The Authors, 2013, p. 893).

Earlier studies of enthusiasm emphasized how it was 'the bedrock of everyday culture and leisure activity' (Bishop and Hoggett, 1986, p. 3). However, studies of enthusiasm have, more recently, broadened from a focus on leisure activities and voluntary work, to acknowledge how enthusiasm plays out in professional and policy settings. Doing so demonstrates some of the more ambivalent aspects of enthusiasm, including associations with amateurism and emotional (rather than rational) decision-making. In the $17^{\text {th }}$ and $18^{\text {th }}$ centuries enthusiasm was associated with dangerous religious fervor and extremism. Whilst this understanding is less relevant today, enthusiasm can still be seen as a negative or ridiculous trait, associated with fandom, obsession, geekiness, or amateurism (Geoghegan, 2013). For example, despite the fact that recent work has 
highlighted the value of working with enthusiast groups in academic research (Geoghegan, 2014), academics are often guilty of categorizing enthusiasts as untrained and irritating amateurs (Samuel, 1994). In Geoghegan's (2009) study of industrial archeology, professional archaeologists (in university and private practice) resented and denigrated the work of amateur archaeologists, despite the fact that they often possessed specialist knowledge of particular sites. The lack of value placed on the (often considerable and specialized) knowledge of enthusiasts is based in part on the coupling of emotion with the expertise that enthusiasm often produces. Enthusiasm in this context undermines objectivity. As Anderson and Smith (2001) note, the point that emotion is both neglected and suppressed in knowledge production more broadly is hardly new. Yet the artificial divide between supposedly objective rational knowledge and emotional reaction remains powerful.

Hardill and Mills (2013, p. 321) note that although "[e]vidence-based policy and practice operate on a belief that knowledge is obtained through objective observation and reasoning", in fact, policy-making is far more intertwined with the social world: "the work of producing such knowledge is typically more 'messy', more iterative, and more non-linear"(ibid.). This work builds on earlier studies by STS scholars such as Wynne (1996) who sought to challenge the uncritical definition of what constitutes expert knowledge. Remedying the long-term neglect of 'grassroots' or lay knowledges surrounding environmental issues, Wynne's work revealed lay responses to expert decisions, and how the admission of less bounded notions of what constitutes expert and lay knowledge can lead to "alternative, more culturally-rooted and legitimate forms of collective, public knowledge"(1996, p. 46). Following this Ellis and Waterton's (2004, p. 100) study of the participation of naturalist volunteers in biodiversity policy revealed the need to pay close attention to the ways in which policy and volunteer identities converge and diverge, specifically how volunteers "move in between a world of responsible biological recording in the name of conservation and a world of passionate engagement with nature".

More recently, the emotional dimensions of knowledge production and lay-expert relationships have come to the fore (Horton and Kraftl, 2009). For example, Cass and Walker (2009) explore the use of emotion in planning decisions. They highlight how because the 
planning process is meant to be "rational, reasoned and objective" (ibid., p. 66), emotional responses are not considered relevant to planning applications. In their study, planners and policy-makers characterised community responses as emotional. This was part of deliberate strategic moves to dismiss and devalue their concerns. Their work shows that activists were well aware of the need to manage the way that emotional language and reactions were presented to decision-makers in order to retain credibility and thereby influence actions and outcomes (Cass and Walker, 2009).

In Anderson's (2014 p. 19) study of the role of activists in policy-making, she highlights the ways in which different forms of knowledge could be valued in making decisions, drawing attention to a division between "abstract, technical and third-hand knowledge about the world and personal, visceral and first-person knowledge". Both were legitimate, but emotion was only associated with the latter. Thus, as she argues, in policy work, "a wider system of knowledge that understands rationality and emotion to be two essential but irreconcilable ways of knowing and being in the world" is enacted (ibid., p. 22). Within this binary, activists were called upon to perform emotional personal knowledge in policy-making circles, for several reasons. Emotion was seen as an important 'moral corrective' to the bureaucratic knowledge of professionals (ibid., p. 19). Though these professionals needed access to these emotional knowledges, to display these forms of knowledge themselves would have destabilized their own rational performances. Emotions, including enthusiasms, have unpredictable consequences for those "beholden to professional guidelines and structures", consequences which are in need of further investigation (Geoghegan, 2013 p. 45).

Using concepts of performance and dramaturgy, Anderson (2014) also shows how by playing the 'fool', the activist is able to work within policy arenas in an often uncomfortable but productive way, destabilising and challenging bureaucratic responses. As her work demonstrates, objectivity and professional language often close down the options for thinking differently about how to take action. Emotional responses and alternative modes of performing in policy practice might offer opportunities for organisations to affect change. Emotion can therefore be used in many ways: as a label in order to dismiss certain (often oppositional or activist) knowledges, or 
deployed strategically to destabilise technical or professional performances. It must be expressed and suppressed "when and where appropriate" (Geoghegan, 2013, p.42). This presents a series of questions: what are the consequences of all this for enthusiasm, and for those working between the category of activist and professional? What are the opportunities and risks of enthusiasm in policy work?

In many organisations, particularly those within architectural conservation, work is carried out by a number of paid and voluntary staff, all of whom are enthusiasts, and many of whom are also trained 'experts', whether they work for the cause voluntarily or on the payroll. In these cases, the activist, amateur or volunteer (with each holding different resonances, see Eliasoph 2009) may hold knowledge that blurs the boundaries between that imagined as emotional and grounded, and that understood as expert and rational. In what follows, we explore the consequences of architectural enthusiasm across the work of the Twentieth Century Society.

The next section introduces the Society more fully and explains our methodological approach to enthusiasm. After this, three sections explore enthusiasm at the Twentieth Century Society. The first describes how people engage with the society as members and volunteers, and the role of enthusiasm within this. The second section explores how this passion for modern architecture is understood by key members of the Society as residing in only some of its activities, and demonstrates that enthusiasm is better conceptualised as working across all elements of the Society's work and activities. Building on this insight, the third substantive section explores how in the Society's campaigning work enthusiasm is both central, and carefully managed, in order to maintain a performance of rational expert knowledge. We conclude by noting how this ambivalent relationship with enthusiasm might circumscribe alliances with other sorts of architectural enthusiasts and new and emerging forms of campaigning.

\section{Tracing Enthusiasm in the Twentieth Century Society}

The Twentieth Century Society's main office is in central London, with semi-autonomous regional groups that support their work nationally. There is a paying membership of around 2,000 people who pay their subscription of $£, 50$ per year. Their statutory advice role is carried out 
by two full-time and two part-time staff members: a Director; a Co-ordinator; and two Conservation Advisors (prior to 1991 the Society was run by volunteers). The Society started receiving funding from the British Government in 1997 to support its casework, a move that put them in line with other National Amenity Societies with statutory roles (e.g. The Georgian Group, The Victorian Society). However, this grant has only ever covered around 50\% of the Society's casework costs, with the remainder predominantly funded by membership and income from events (Minutes of the Twentieth Century Society Annual General Meeting 2014).

The Society works towards two objectives: "conservation, to protect the buildings and design that characterise the twentieth century in Britain, and education, to extend our knowledge and appreciation of them" (see www.c20society.org.uk). These objectives map roughly onto the two areas of activity in which the Society is engaged, with the paid staff spearheading the conservation and policy-oriented work of the Society, and volunteers leading the educational and event-based activities they run. Conservation work includes fulfilling a statutory role of providing advice and assistance directly to Historic England ${ }^{1}$ (the government funded organisation that makes decisions over which buildings will be listed) by proposing buildings for heritage designation and protection, and campaigning to save threatened buildings. Events include walking tours, coach trips, lecture series and members 'slide evenings'. Typically, therefore, members of the Society associate enthusiasm with the social and educational strand of the Society's activities, which are run by volunteers, with support from paid staff, rather than with its statutory advice and campaigning role. However, as we will go on to show, this is a strategic simplification: voluntary labour supports both strands of the Society's work, and enthusiasm is important across all of its activities. However, due to the uncertain relationship between enthusiasm and expertise, policy-making and rationality, the role of enthusiasm is not always visible to the individuals or organisation.

\footnotetext{
1 Historic England is the government funded organisation that makes decisions over which buildings will be given statutory protection, or listed. Formerly known as English Heritage, Historic England was formed through the decision to split the 'access to heritage' and 'statutory planning and conservation' functions in 2015. English Heritage now manages a large estate of historic buildings, while Historic England focuses on policy and conservation.
} 
The ambivalence with which enthusiasm is sometimes viewed means that it is, like emotion more broadly, difficult to research, particularly in professional settings. Anderson's (2014) study of the role of emotion in policymaking highlights the need to rely not only on interviews, but also on participant observation, in researching emotion, expert knowledge and the role of the activist. Jones and Yarrow (2013), too, demonstrate the value of an ethnographic approach including observation of work, guided tours, informal conversations and interviews in understanding conservation practice as an embodied, messy process involving multiple actors and negotiations over authenticity and value. Here we use similar methods in an attempt to understand the role of enthusiasm in the work of architectural conservation carried out by the Twentieth Century Society. We draw on ethnographic work with the Society, including participation in public and member events (walks, talks, slide-shows), observation of committee meetings (related to the organisation of events and Society 'casework' about buildings in danger or listing applications), and in-depth interviews with paid staff, trustees, committee members, other volunteers and paying members, all of which were carried out between 2012 and $2014 .^{2}$

Dialogue with the Society was an integral part of our approach, which included a daylong workshop where volunteers and paid staff were invited, along with other representatives from the heritage sector (Heritage Alliance, National Trust, Historic England), to reflect upon the role of architectural enthusiasm in their work. In the course of these discussions, as well as in our interviews, our conceptualisation of architectural enthusiasm was sometimes rejected. These discrepancies between our observations and the way the Society is presented by its Director and Trustees does not invalidate our findings, rather it demonstrates the ambiguous nature of enthusiasm for such organisations. In turn, this highlights the need to research enthusiasm through ethnographic approaches, rather than relying solely on the descriptions given by those involved. To accept this official narrative is to only partially understand how the Society's work gets done. Engaging with the Society through interviews but also observation and participation allowed us to witness how the rejection of enthusiasm acted to both mask the productive value

\footnotetext{
2 Permission was gained from all research participants to quote from their interviews, and to include names or job roles where necessary.
} 
of enthusiasm in architectural conservation as currently practiced by the Society, and to potentially limit opportunities for engaging with architectural enthusiasm in new ways.

\section{Membership, Enthusiasm and the Twentieth Century Society}

The Twentieth Century Society's membership can be broadly characterised as generally white, middle class, and often older (retired) individuals. Though members are fairly uniform, their engagement with the Society is highly variable. Members display a whole spectrum of engagement, from passive (paying their subscription, receiving the Society's publications, but not actively participating in events) through to very active (participating in multiple events, or volunteering for the Society). Unlike the architectural profession, and many other enthusiast groups, which are dominated by men (Stratigakos, 2016; Bennett 2013), there is gender parity across honorary positions (e.g. chair, treasurer, membership secretary, events co-ordinator) and trustees with the majority of the key professional roles (director, conservation advisors) - which are linked to the Society's central London office - filled by women.

Whilst the Twentieth Century Society tends to privilege quite a narrow idea of 'architects' and 'architecture' in their work, these are by no means the only interests of members. Instead there are different pockets of expertise, for example those who are fascinated by interior design or social history, buildings that represent the growth of urban areas, such as churches, cinemas and crematoria, or particular architectural styles, such as Art Deco, Scandinavian Modernism or Brutalism.

It is very easy to become a member of the Twentieth Century Society. However, sustained, active participation, namely engagement with the Society that goes beyond paying dues, reading the quarterly magazine, and occasionally attending an event, is primarily the remit of a small number of individuals. An identifiable group of committed architectural enthusiasts do much to support the work of the society on a voluntary basis, such as joining committees, supporting case work activities, organising walks, offering talks, or writing for the magazine. This important group reflects a desire to volunteer time and energy to support the core functions of 
the Society in roles such as secretary, treasurer, or casework convenor that transcend the initial interest in modernist architecture.

The Society fosters and facilitates architectural enthusiasm not only amongst individuals, but also as a shared passion, through its events such as tours, lectures and social events. Pleasurable activities are a longstanding part of the Twentieth Century Society's remit. Remembering the early days of the Society, one member commented that:

“one of the things we used to do which was more fun, we used to go on trips and they'd use a sort of thirties omnibus or something like that. You know...it was slightly more of an event...[it was] more about the frivolity of the thirties, the dressing up and that kind of thing"(Interview Society Member and Volunteer).

Walking tours and coach trips remain central to the Society's offering to its membership, providing an opportunity to share enjoyment of architecture. Observations of these tours highlight the conviviality of the events - demonstrated in humour, friendship, shared joy at buildings - and the ways that these worked to sustain member participation and interest (The Authors, 2013). Tours and other member events are run by volunteers who staff the Events Committee. This committee comes up with a programme of activities and volunteers spend significant amounts of personal time preparing for the delivery of walks, talks, and tours. Volunteers are important to the society because they run the majority of the Society's member events and sustain the membership subscriptions that are a significant and crucial income stream. Those taking on such active roles report they do this because they are motivated by a strong desire to share, educate, and excite others about 20th-century architecture (Authors' Interviews). Thus those more actively involved in the Society are motivated by enthusiasm for architecture, which is in part about the conviviality of a passion shared.

Often, volunteering builds on interconnected personal and professional interests in architecture with professional training in architecture, planning, heritage and conservation common amongst those participating actively. For them, the overlapping interests of Society 
members on tours provides, as one Society member - a conservation officer with a London Borough Council who also leads tours occasionally - noted, "an informal network of people" with different interests, on which to draw professionally, but also with whom it is possible to share - and develop - enthusiasms and concerns (Author's Interviews). The cultural capital of some members incorporates their extensive knowledge of one or more architects, architectural genres, building types or architecture in particular geographical locations, often borne of previous study or professional training, but also of enthusiastic research outside of formalised learning. Expertise can therefore come from different places, but is performed and valued by the Society when evidenced in well-researched and accurate walking tours, successful event organisation, an understanding of the demands of casework, and high quality listing applications. Thus volunteering for the Society relies upon a series of pre-determined expectations about architectural enthusiasm drawing on expertise - it would be very difficult to be an active volunteer without substantial knowledge of architecture, planning and conservation. In the next section we move on to discuss how enthusiasm for modern architecture is on the one hand crucial to the work of the Society, yet it is also something that has an awkward position in the realm of conservation as professional practice.

\section{Enthusiasm and Professional Practice at the Twentieth Century Society}

Since the beginnings of the Society in 1979 as the Thirties Society it has become more professional in its operation - both in terms of employing paid staff and formalising its working practices (see Hilton et al., 2012 for wider commentary on the professionalization of the voluntary and charitable sectors). This shift has resulted in a change in emphasis, from events to campaigning. Reflecting on the change in emphasis on different parts of the Society's identity, the Society's Director suggests that as the Society has "become a more professional organisation, we've very much wanted to keep a lot of the very positive aspects of our original, more amateur formation", what could be seen as the "clubby membership side of our psyche". However, this in turn raises its own fears. Would including "a far greater kind of communal and fun element undermine our credibility as a professional organisation?" (Interview with Society Director). Such 
concerns illustrate the fragile performances of professional expertise within such an organisation, which is run predominantly by volunteers and embraces a membership driven in part by desires for sociability, play, and shared interests (see also Edwards, 2009).

Reflecting on the "relationship between enthusiasm and professional practice" within the Society, its Director was circumspect: “I don't know that I'd really thought about what we were doing as an emotional experience. Maybe that's because I've always been on the casework side where I feel that what we've been doing is trying to make very rational arguments for conservation". These comments were made at a public conference and can be seen as a presentation of the organisation which deliberately delimits the role of enthusiasm and emotion it its work. This explanation reflects and reinforces an understanding of the work of the Society as divided between the two sides set out earlier: the volunteer led, enthusiasm fuelled, members club, and the Society's conservation work, led by paid professionals. This division is strategic, representing an important way of delimiting the role of enthusiasm in the Society's work. This characteristic division underlay many of the interview discussions with society employees and active volunteers. Below we explore the ways in which voluntary work, often prompted in part by enthusiasm, although often bracketed off as 'fun work'/fundraising, also contributes to the Society's "very rational arguments for conservation". We also demonstrate that enthusiasm is not the sole preserve of volunteers; paid staff at the Society are also motivated by architectural enthusiasm, as well as by professional roles.

Although they are often associated with the more social aspects of the Society, volunteers often play an important role in the 'professional' side of the Society's work: its statutory advice and its campaigns. When asked about the role of volunteers, one trustee noted that volunteers are involved in the technical side of the Society's work as well: "we have one particular guy who does listing applications ... and very good ones" (Interview with Society Trustee). Other volunteers sit on the Society's Casework Committee, a panel of experts supporting the work of the Society's paid Conservation Advisers, or provide advice to paid staff on an ad hoc basis. The Casework Committee is "made of architectural historians, architects, planners, one or two knowledgeable laymen [sic]" (Society Trustee), with this pool of 
professional-volunteers dominated by people who have "professional knowledge" (Interview with Society Director). These volunteers effectively extend the expertise held within the Society (as in many similar organisations, see Lowe, 1977; Glendinning, 2012; National Council of Civil Trust Societies, 1990).

Some people who volunteer for the Society also work for Historic England. As one of the Society's Conservation Advisers explains: "there's a lot of double counting that goes on, as we have a lot of members and committee members and trustees who're English Heritage" (now Historic England). For example, Elain Harwood, Senior Architectural Investigator at Historic England was a Society Trustee, is an active member of the events committee, has served on the casework committee, has run Society events, and often writes for the Society's magazine.

For the Society, such expertise offers both highly specialised knowledge about modernist architecture, and networks into other important conservation bodies. Harwood's position highlights "the porosity of boundaries between the state and civil society", particularly within conservation-planning (Hewitt and Pendlebury, 2014, p. 32). While (2007, p. 646) has suggested that campaigners for modern architecture in the UK, such as the Twentieth Century Society, are "located within and outside the state in promoting, lobbying for, and defending the conservation of post-war modernist architecture and planning", but that very little is known of this active community of "post-war conservation champions" (p. 660). Our work therefore reveals what While (2007, p. 646) calls the "'hidden' politics of decisions about the direction of post-war listing taken at the national level," drawing out the complex ways that state and non-state advisory groups interact and operate within this. Understanding the Twentieth Century Society's place within a wider network of conservation practitioners highlights the interconnections between members and employees of the Society and other conservation, architecture and planning bodies and the way that these individuals are motivated, and connected, through enthusiasm.

For people like Harwood, architectural enthusiasm spans personal and professional interests and is clear across her many books, public talks and TV appearances (Harwood, 2003; 2010; 2015). Harwood's pattern of engagement with the Society demonstrates the way that 
individuals work across the divide of professional conservation work on the one hand, and members interest club on the other. Harwood's position is not unique, in fact her professional and personal enthusiasm for modern architecture reflects a good proportion of Society members, and the vast majority of those who are involved with the Society more actively as volunteers. Whilst "the embodied position" adopted on Society tours, and through other social events, reveals a passion for buildings (The Authors, 2013), other roles for the Society require the projection of a more objective form of expert knowledge. Within policy-oriented and consultation work enthusiasm is deemed to be a potentially undermining presence, and something which is outwardly downplayed. This is facilitated by the structure of the Society that creates a division between events and education (where enthusiasm is embraced) and casework (where enthusiasm is denied).

\section{Casework, Professional Expertise and Enthusiasm}

A Casework Committee meeting - complete with the standard apparatus of agenda, boardroom, and minutes - provides a good example of the performance of abstract, disembodied expert knowledge: the antithesis of enthusiasm. Taking place in the offices of a London architectural firm, the location highlights both the professional roles of those volunteering for the Society and the formality of the meeting itself. Yet those sitting around the table, with agenda and case files in front of them, are often the same people who speak passionately about architecture on walking tours, at lecture nights and other events. Observation of a case work committee meeting, in 2013, revealed the discussions to be anything but devoid of emotion. Reports on 'lost' conservation battles elicited concern and misery, whilst ongoing cases were the focus of passion, and devotion. Conservation advisors and volunteer committee members alike drew explicitly on their own emotional responses, stating their love of and dedication to certain buildings. This overlapped with, and indeed was integral to, discussions about formal process, planning, and regulations. Moreover, a passion for modern architecture was central to bringing together a collection of nine highly qualified people on a wet Monday night in September, many of whom had arrived straight from full-time jobs. Whilst committee meetings were often lengthy and serious, they did not 
occur without emotional engagement. However, the committee functions to formalize volunteer work, securing it as expert, rather than amateur labour, and to distance the work of this committee from emotion. The fact that the committee's work is partly performative was acknowledged by one Trustee: "[I often wonder] whether casework committee is adding anything to the process other than gravitas. I think it's quite useful to be able say there is one... 'We will take it to our expert committee"' (Interview Society Trustee).

By contrast, a meeting of the Events Committee, relating to the organisation of walks and other social events for the Society took place in the bar of the Barbican Centre - a brutalist arts centre in London. At this meeting enthusiasm led the agenda, as it was dominated by offers of walks and other events which drew explicitly on volunteer's interests, or were seen as likely to be enthusiastically received by the wider membership. Here too, unbridled enthusiasm had to be managed however: suggestions deemed too obscure or lacking suitable expertise were rejected. The different settings for committee meetings reflects different levels of formality and professionalism. Serious, professional discussion of casework takes place in the offices of an architectural practice, while the more relaxed atmosphere of a bar in an arts centre is better suited for planning events.

In our work with the Twentieth Century Society, emotion plays a less clear role when activists are engaging with professionals (see Anderson, 2014). Whereas activists are often associated with first hand, emotional knowledge of a situation which acts as a counter to the abstract rational knowledge that professionals must perform, in the case of the Society's volunteers, they, too, must perform as experts. Volunteering for the Society in their casework, individuals are required to fulfil a role as, what Hewitt and Pendlebury (2014, p. 34) call, "expert citizens" - providing professional expertise to fill gaps in official knowledge or paid positions for the Twentieth Century Society. The Society, in turn, fulfils this role for national and local government. Unlike community groups, who are often seen as valuable as sites of "lay knowledge" (ibid.), which is understood as emotional, embodied and grounded in local contexts (Anderson, 2014), organisations like the Twentieth Century Society are valued as sites of expert and rational knowledge. Thus whilst the work and activities of the Society are undergirded by 
enthusiasm - driving membership and volunteering - this enthusiasm must be managed. The challenges they face are familiar: how to manage emotions in professional settings where emotional responses - rather than being seen as enabling and grounded, are regarded as destabilising and undermining (see Hawkesworth and Imrie, 2009; Imrie and Street, 2009 for discussions relating to allied fields of architecture and building control).

Beyond motivating volunteers, and even paid staff (who could often take on more lucrative positions elsewhere), to be involved with the Society, enthusiasm is central to successful campaigning practice. Enthusiasm for buildings expresses itself in the form of hours of archival research that is incorporated into listing applications, one of the key strategies adopted by the Society to protect buildings. Although listing procedures rest on supposedly rational judgements of architectural quality, there is room for enthusiasm within this:

“[E]nthusiasm's very important, even within the constraints of the criteria you have to follow. We use a lot of opinions and quotes from authorities, on a particular building. So the opinion on its quality or the opinion of its design strength or something is part of the enthusiasm for it, so we will use our trustees or our members, or people's particular expertise in that, quote their enthusiasm as part of the justification" (Interview Society Conservation Adviser, emphasis added).

Enthusiasm in the form of expert opinions can therefore have a place within planning rationales and highlight the architectural value of threatened buildings. Thus although "on one level you've got criteria, objective criteria to follow... how those are interpreted, really is not very objective" (Interview Society Director).

The designation of Brutalist style Preston Bus Station as Grade II listed in September 2013 exemplifies how enthusiasm for a particular building intersects with and sometimes drives professional practices highlighting the blurry boundaries between the enthusiast and the professional. The bus station had long been a campaigning focus for the Twentieth Century Society, championed by both its North West regional group, and also the central office. This resulted in several listing applications in response to threats that the building might be demolished as part of plans to regenerate Preston city centre (see Toogood and Neate, 2013). 
The first application was submitted in 2000 but rejected. A second submission was prepared and submitted in 2010 by a Conservation Adviser working part-time for the Twentieth Century Society; this was also rejected. However, following the announcement in December 2012 that Preston City Council had voted to demolish the bus station, the Twentieth Century Society stepped in again with a final application.

This application was written by the same person who prepared the 2010 submission, though by 2013 they were no longer working for the Society. Thus this final attempt was primarily the result of passion, as she recalled: "I have to say, through my involvement, I had fallen in love with the building" (former Society Conservation Adviser Interview). In our interviews with Society staff and volunteers there were often similar unprompted articulations of excitement for and love of buildings because of the way they "smell, how it feels like to be in them", or how some had been driven to become involved in campaigning because they were responding to "gut feelings" (see The Authors, 2013). Here, this passion for the bus station had accumulated through a period of paid work for the Society. But it continued far beyond the end of this formal role, and prompted hours of voluntary work uncovering further archival documentation and rewriting the application. Between 2010 and 2012, public opinion over the bus station had substantially changed, with the building subject to widespread campaigning (including local campaigns, international heritage bodies, and artistic and creative responses, see Toogood and Neate, 2013). Whilst this public enthusiasm undoubtedly played a role in the decision to list the bus station at the third attempt, it was the formal evidence presented in the listing application that resulted in the listed status announcement of September 2013.

The outcome for the Preston Bus Station campaign was a good one for the Society, demonstrating the role of passion and care in listing. It has been a success story that the Society is happy to promote. Here success allows enthusiasm to be acknowledged, though conversely, failed attempts to get buildings listed tend to be framed as laments over the inability of those making decisions to 'take seriously' the expert opinions and recommendations of the Society. This speaks to the ambiguity of enthusiasm. Too often enthusiasm can be conflated with obsession, and anorak tendencies, which at best are tolerated and at worst are seen as 
impediments to level headed decision-making. As Edwards (2009, p. 296) argues, this catches the Society in a "double bind: the very 'enthusiasm' is assumed to translate into an uncritical approach.” One Conservation Adviser noted that in contrast to other bodies, such as Historic England: "we tend to be the extreme views". This comment came with a remark that sometimes this enthusiasm had to be tempered: "we have to be a bit careful because we don't want to come across as too extreme, we'll lose our credibility" (Interview Conservation Adviser). Thus the Society's campaigning role requires a double performance, and involves a complex relationship with enthusiasm, where enthusiasm is positioned as both extremism and motivator for action. We see how passion must be cultivated to provide financial support and volunteer labour for the campaigns, but in a mode of engagement predicated on professionalism and expertise, and performed through formal processes of committees and written applications, it must also be seen to be moderated. As one interviewee commented it is not always helpful to be seen as the “anoraks of concrete architecture" (Interview Society Member and Volunteer).

Because enthusiasm is considered as something that has to be managed in order to maintain professional credibility, it can make enthusiast and volunteer groups blind to the important role that enthusiasm has within their work. Within architectural conservation this manifests itself in a generally upheld pretence of rationality, and this is a position that is rarely challenged because of fears of undermining professional standards and credibility. Yet it does narrow down how enthusiasm might be used in different, potentially more creative ways that move beyond the traditional parameters that are set out as the acceptable boundaries of architectural conservation. This is particularly relevant to consider at a time when modern heritage is being campaigned for and protested about by all sorts of different and wider groupings, most of whom are enthusiastic for particular examples of built heritage, though are coming from very different frames of reference and value systems to the Twentieth Century Society. For example, the 'Long Live Southbank' campaign led by skateboarders claimed different sorts of value for this architectural space through a high profile social media strategy and also tried to intervene in official planning process (see Mould 2014). Similarly, in discussion of the Apollo Pavilion in Peterlee, Farmer and Pendlebury (2013) demonstrate how sites of 
modern heritage are easily co-optable by heritage discourses, and from intervention and support from 'elite' heritage and conservation organisations (such as the Twentieth Century Society). However, they also reveal how modern heritage can be resistant to such clear-cut positioning, demonstrating how local cultures can privilege different values that work outside of policy frameworks, the result being ongoing contestation around value and ownership, rather than sites straightforwardly becoming 'part of a warm, comforting blanket of heritage' (ibid p. 263).

As Catherine Croft, the Society's Director commented: "We are at a stage where our view of how the public involvement in preservation and what the basic tenets of what the movement are, is in a bigger state of flux than it has been for a very long while" (Croft, 2013). What this means for the Twentieth Century Society, and other similar bodies is a pertinent question and speaks of potential alliances with groups who do not necessarily align themselves with the same aims and goals of architectural conservationists. As a result, the traditional landscape of architectural conservation is opening up to new and different practices being employed by other groups and diverse sets of architectural agents. Exploring the shared ground, enthusiasms-in-common and complementary demands between obvious and unlikely 'community' and 'activist' groups makes space for more accommodating understandings of architectural value, and more nuanced conceptualisations of enthusiasm as emotion and practice. Alliance building, for groups like the Twentieth Century Society, might be a productive way of articulating other regimes of value (political, or social for example) for buildings that their particular position in the planning process, that values rational argument, largely prevents.

\section{Conclusion}

Focussing on the management of enthusiasm as an emotional affiliation, this paper has drawn out the tensions between enthusiasts who might be categorised as 'amateur' and often work as volunteers, and paid staff who may also be enthusiasts. We outline below why it is important to understand enthusiasm in such contexts.

This paper firstly demonstrates how methodologically it is possible to trace enthusiasm. Focussing on the operations of the Twentieth Century Society, we used ethnography, specifically 
interviews and participant observation to reveal not only what groups say they do, but also what they actually do. By spending time with those who volunteer and work for the Twentieth Century Society, we were able to understand how volunteers and professionals think about enthusiasm and how it relates to their work. Engagement of this type allows researchers to understand enthusiasm and its associated tensions and ambiguities on the terms set by the participants themselves, as well as refine and challenge what enthusiasm might mean conceptually. This is important in the study of enthusiasm because many of the issues relating to the management of enthusiasm occur beneath the surface and are often denied. Paid staff may not be aware that they may be discriminating against volunteers or disrespecting their expertise. Simultaneously, enthusiasts are not always able to contain their zeal and remain unaware of the challenges this may pose professionally.

Second, enthusiasm is productive. It is a driver and enabler behind much of what groups and societies like the Twentieth Century Society do and as such can be viewed as a positive emotional affiliation and disposition. This type of 'obvious' enthusiasm takes the form of individuals joining a society, being part of a membership, sharing interests around particular issues, and importantly paying a subscription that funds any professionals employed by the society. Yet this enthusiasm is far from passive, those who want to can volunteer their time to a range of activities and events, whereby enthusiasm becomes a source and focus for sociality, and an opportunity to share and generate knowledge (see The Authors, 2013).

Third, although enthusiasm has productive capacities, our investigation of the workings of organisations like the Twentieth Century Society, revealed how it also requires careful management, and on occasion denial, particularly when the goal is to influence decision-makers across a range of fields. In the case the Society, some of the membership drew a line between its social, events-based activities and its casework and campaigning in order to maintain a credible, professional identity. However, the positioning of some activities as objective and rational is the end product of a much longer and complex process imbued with emotional engagements, value judgements and enthusiasm. Indeed, enthusiasm and associated passions run throughout the enthusiast and professional aspects of the Society, from passive members who pay their dues and 
in turn the salaries of the paid staff, through to volunteers who staff committee meetings and employ their professional expertise in casework activities, as well as paid members of staff. Enthusiasm as emotion also motivates people (who typically have 'paid' professional lives elsewhere) to take on voluntary activities to help further the causes and work of their group or society. Yet, not all volunteers are regarded or positioned as enthusiasts. Instead, for reasons of, first, managing the sometimes negative baggage that comes with an emotion like enthusiasm, and, second, for maintaining professionalism and credibility, they are placed in the category of 'experts'. This manifests itself with the adoption of various bureaucratic and administrative procedures, in this case expert committees that are serviced by individuals who carry out this labour in addition to other professional commitments.

Our account of enthusiasm and associated arguments in this paper contribute to the growing literature on enlivening accounts of volunteering and professional identities, practices and networks. Further questions remain about the situated and embodied character of enthusiasm within seemingly fixed or ordered legislative and policy fields/frameworks. We must improve our understanding of how these enthusiast groups contribute to changing the worlds around them - locally, nationally, politically, and with what consequences. This requires a more detailed appreciation of the construction and performance of enthusiast-volunteer and enthusiast-professional identities of individuals and groups, such as the amenity societies with statutory remits, as well as better notions of who participates in these practices and where (see The Authors, 2015; Brownhill and Carpenter, 2007). These broader questions are particularly relevant at a time when volunteer labour is becoming increasingly crucial against a backdrop of austerity. The last five years have seen swingeing cuts to local authorities' budgets including those for architectural conservation, reduced national government funding towards the amenity societies' statutory roles, and an increasing volume of casework (Interview with Society Director; Report of the Trustees and Financial Statements 2015).

Finally, our research with this one relatively small organisation serves here as an example of the numerous similar conservation and built-heritage groups worldwide (though chiefly in the West). Yet our arguments also resonate with other related groups, for example small museums, 
archives and industrial heritage sites that are run and maintained by dedicated teams comprised of volunteers and professionals. These groups rarely feature in academic study, though as we have argued elsewhere, they play a vital role in "doing and making civic geographies" (The Authors, 2015 p. 374). The passions and tensions evident in this paper underpin enthusiastic pursuits and the state-voluntary sector nexus, and are not restricted to architectural conservation. Paying close attention to these emotional tensions is increasingly important, particularly as organisations grow and responsibilities, constitutions and demands shift and compete, and political and funding landscapes change.

\section{References}

Anderson, K., Smith, S., 2001. Editorial: Emotional geographies. Transactions of the Institute of British Geographers 26, 7-10.

Anderson R., 2014, Playing the fool: Activists' performances of emotion in policy making spaces Emotion, Space and Society 13 16-23.

Bennett, L., 2011. Bunkerology—a case study in the theory and practice of urbex. Environment and Planning D: Society and Space 29, 411-434.

Bennett, L. (2013) Who goes there? Accounting for gender in the urge to explore abandoned military bunkers. Gender, Place and Culture 20, 630-646.

Bishop, J., Hoggett, P., 1986. Organising Around Enthusiasms: Mutual Aid in Leisure. Comedia, London.

Brown, G., Pickerill, J., 2009a. Editorial: activism and emotional sustainability. Emotion, Space and Society 2, 1-3. 
Brown, G., Pickerill, J., 2009b. Space for emotion in the spaces of activism. Emotion, Space and Society 2, 24-35.

Brownill, S., Carpenter, J., 2007. Participation and Planning: Dichotomies, Rationalities and Strategies for Power. Town Planning Review 78, 401-428.

Cass, N., Walker, G., 2009. Emotion and rationality: The characterisation and evaluation of opposition to renewable energy projects. Emotion, Space and Society 2(1), 62-69.

Chatterton, P., Pickerill, J., 2010. Everyday activism and transitions towards post-capitalist worlds. Transactions of the Institute of British Geographers 35, 475-490.

Croft, C., 2013. LLSB at the Architecture Foundation. http://www.llsb.com/llsb-at-thearchitecture-foundation

Delyser, D., Greenstein, P., 2015, “Follow That Car!” Mobilities of Enthusiasm in a Rare Car's Restoration. The Professional Geographer 67(2), 255-268.

Edwards, B., 2009. Concrete watching: networks of architectural activism. In Glynne, J., Hackney, F., Minton, V. (Eds.) Networks of Design: Proceedings of the 2008 Annual International Conference of the Design History Society (UK). Universal-Publishers, Boca Raton, Fl, pp. 294-300.

Eliasoph, N., 2013. The Politics of Volunteering. Polity Press, Cambridge.

Ellis, C., Waterton, C. 2004. Environmental citizenship in the making: the participation of volunteer naturalists in UK biological recording and biodiversity policy. Science and Public Policy 31 (2), 95-105. 
Everett, G., Geoghegan, H., 2015. Initiating and continuing participation in citizen science for natural history. BMC Ecology. [n Press]

Farmer, G. and Pendlebury, J. (2013) Conserving Dirty Concrete: The Decline and Rise of Pasmore's Apollo Pavilion, Peterlee. Journal of Urban Design 18, 263-280.

Geoghegan, H., 2009. 'If you can walk down the street and recognise the difference between cast iron and wrought iron, the world is altogether a better place': being enthusiastic about industrial archaeology. M/C Journal: a journal of media and culture 12, n.p.

Geoghegan, H., 2013. Emotional geographies of enthusiasm: belonging to the Telecommunications Heritage Group. Area 45, 40-46.

Geoghegan, H., 2014. A new pattern for historical geography: working with enthusiast groups and public history. Journal of Historical Geography 46, 105-107.

Glendinning, M., 2012. The Conservation Movement: A History of Architectural Preservation. Routledge, London.

Hardill, I., Mills, S., 2013. Enlivening evidence-based policy through embodiment and emotions. Contemporary Social Science 8(3), 321-332.

Hawkesworth, M., Imrie, R., 2009. Organisational change in systems of building regulation and control: illustrations from the English context. Environment and Planning B: Planning and Design 36(3), 552-567.

Hemming, H., 2011. Together: How Small Groups Achieve Big Things. John Murray, London. 
Hewitt, L. E., Pendlebury, J., 2014. Local associations and participation in place: change and continuity in the relationship between state and civil society in twentieth-century Britain. Planning Perspectives 29, 25-44.

Hilton, M., McKay, J., Crowson, N., Mouhot. J-F., 2013. The Politics of Expertise: How NGOS Shaped Modern Britain. OUP, Oxford.

Harwood, E., 2003. England: A Guide to Post-war Listings. Batsford, London.

Harwood, E., 2010. Keeping the past in England: the history of post-war listing. The Journal of Architecture 15, 671-682.

Harwood, E, 2015, Space Hope and Brutalism: English Architecture 1945-1975 Yale University Press.

Horton, J., Kraftl, P., 2009, What (else) matters? Policy contexts, emotional geographies. Environment and Planning A 41, 2984-3002.

Imrie, R., Street, E., 2009. 'Regulating Design': The Practices of Architecture, Governance and Control. Urban Studies 46(12), 2507-2518.

Jacobs, J. M., Merriman, P., 2011. Practising architectures. Social and Cultural Geography 12, $211-222$.

Jones, S., Yarrow, T., 2013. Crafting authenticity: An ethnography of conservation practice. Journal of Material Culture 18(1), 3-26. 
Jupp, E., 2012. Rethinking local activism: 'Cultivating the capacities' of neighbourhood organising. Urban Studies 49(14),3027-3044.

Kitson, J., 2015. Home touring as hospitable urbanism. Journal of Urbanism DOI:10.1080/17549175.2015.1111924.

Lees, L., Baxter. R., 2011. A 'building event' of fear: thinking through the geography of architecture. Social and Cultural Geography 12, 107-122.

Lowe, P. D., 1977. Amenity and equity: a review of local environmental pressure groups in Britain. Environment and Planning A 9, 35-58.

Mills, S., 2015. Geographies of youth work, volunteering and employment: the Jewish Lads' Brigade and Club in post-war Manchester. Transactions of the Institute of British Geographers 40, 523-535.

Mould, O., 2014. "The Southbank and the Skaters: The Cultural Politics of Subversion" http://antipodefoundation.org/2014/02/03/intervention-the-southbank-and-the-skaters-thecultural-politics-of-subversion/

National Council of Civic Trust Societies, 1990. The Relationship Between Civic Societies and Local Authorities. Civic Trust, London.

North, P., Nurse, A., 2014. 'War Stories': Morality, curiosity, enthusiasm and commitment as facilitators of SME owners' engagement in low carbon transitions. Geoforum 52, 32-41.

Roberts, J.M., Devine, F., 2004. Some everyday experiences of voluntarism: Social capital, pleasure and the contingency of participation, Social Politics 11, 280-296. 
Samuel, R., 1994, Theatres of Memory. Verso, London.

Smith, F. M., Timbrell, H., Woolvin, M., Muirhead, S., Fyfe, N., 2010. Enlivened geographies of volunteering: situated, embodied and emotional practices of voluntary action. Scottish Geographical Journal 126, 258-274.

Stratigakos, D., 2016. Where are the Women Architects? Princeton University Press, Princeton.

Toogood, M., Neate, H., 2013. Preston Bus Station: Heritage, Regeneration, and Resistance. North West Geography 13, 10-19.

While, A., 2007. The state and the controversial demands of cultural built heritage: modernism, dirty concrete, and postwar listing in England. Environment and Planning B: Planning and Design 34, 645-663.

Wynne, B., 1996. May the sheep safely graze? A reflexive view of the expert-lay knowledge divide. In Lash, S., Szerszynski, B., Wynne, B. Risk, Environment \& Modernity: Towards a New Ecology. Sage, London. 27-43.

\section{Acknowledgements:}

This research was funded by a British Academy Small Grant (ref: ERI020794). We would like to thank The Twentieth Century Society, their employees, volunteers, and members for their help, time, and support with this research. We would also like to thank the two anonymous reviewers who provided helpful and encouraging comments on a previous draft. 